\author{
E.A. Borzenko \\ Institute of Economics and Forecasting, NAS of Ukraine \\ slozko2003@ukr.net \\ orcid.org/0000-0002-1017-5942
}

\title{
Sovereign ratings of Ukraine: factors and risks
}

\begin{abstract}
Object: The aim of the article is to develop theoretical principles that reveal the content, functions and role of sovereign credit ratings in the financial market, justify the transformation of methodological approaches to determining sovereign ratings in times of crisis, and develop recommendations regarding the regulation of rating agencies in Ukraine.

Methods: The methodological basis of the article was the provisions of general economic theory, a systematic approach, a trend-based forecasting method, analytical alignment methods, and a statistical method.

Findings: As a result of the study, it was found that if a country is assigned a speculative level rating, most of the capital flows into short-term speculative operations. High riskiness, micro and macroeconomic uncertainty, and limited opportunities for the state to influence the economic environment and processes in the country and market participants create an ideal environment for speculative capital movement.

Conclusions: A certain flow of fuse I capi $t$ ala of the real sector in spe kulyativny sector - due to growing risks and the cost of capital is the use of modern tools of business and making financial and economic decisions. Reduce the risks of investors and improve the investment attractiveness are designed such innovative systems and those hnologii as the financial cont ling, value-orientations annoe management, financial co m munikatsii, modern methods of assessment ki credit risks, and the like. Them practical advice in complex e with makroe to nomic reforms in the country will help to improve the ratings of our state as a whole and individual economic entities, create favorable conditions for the inflow of capital into the real economy.
\end{abstract} capital.

Keywords: sovereign ratings, corporate sector of the economy, credit and investment ratings, speculative ratings,

\section{Introduction}

Credit rating industry formation is caused by informational asymmetry on the financial market and the general interest in financial information converting into a simple and clear debtors creditworthiness assessment - a credit rating. For example, in the USA the practice of assigning credit ratings to issuers of debt obligations has been going on for more than a hundred years, while the Ukrainian market of credit rating services has been developing only for the last two decades.

The main reasons for the rapid development of the global rating market are: acceleration of economic and financial globalization, which led to the standardization of risk factors and the need to create an adequate tool for managing the investment portfolio; capital market regulation, including financial crises; development of information and communication technologies that facilitate the rating process.

The purpose of the article is to develop theoretical provisions that reveal the content, functions and role of sovereign credit ratings on the financial market, justify methodological approaches transformation to determining sovereign ratings in times of crisis and make recommendations regarding the regulation of rating agencies in Ukraine.

\section{Literature Review}

The theoretical and methodological basis of the article are publications of foreign and Ukrainian authors, the provisions of general economic theory, a systematic approach to studying the functioning of the market for credit rating services. The crises of the 90 s led to significant transformation in the methodology for determining sovereign ratings: conditional debts (for example, government guarantees) and international liquidity were central to the sovereign default risk assessment; the concept of "selective default" was formulated, approaches to determining the non-payment probability of domestic debt in local currency to foreign public debt in foreign currency were revised. Key parameters of the rating methodology, those are rating horizon (short-term, long-term); definition of an event; rating structure (determination of key factors, its determining and quantitative risk assessments); practice of rating revision (credit warnings and forecasts); 
standardized assessment using a rating scale; creation of a formalized model of the object of assessment are revealed. Requirements for the rating methodology (transparency, accessibility), the same approach to issuers of the same category are a constant adjustment caused by new economic realities.

A review of sovereign (credit) ratings dynamics of Ukraine indicates that the country is often in a predefault state. The investment environment is characterized by a maximum level of risk. A "Ca" rating (Moody's) means not just speculative, but an ultrahigh speculative level with a high probability of default. The end of I quarter 2015 was characterized by the lowest rating among nearly 140 countries. The specified rating class signals that due to a set of adverse factors, investors who invest in Ukraine run the risk of incurring losses. Among the reasons for the high investments risks, Moody's analysts highlight serious geopolitical risks, as well as the likelihood of large losses by external private lenders due to government plans to restructure eurobonds. The negative outlook reflects Moody's expectations that external and public debt levels will remain very high, despite debt restructuring and reform envisaged.

High risk, micro- and macroeconomic uncertainty, limited opportunities for the state to influence the economic environment, the processes in the country and market participants these all create an ideal environment for speculative capital movement. The nature of speculative transactions is explained by the orientation toward situational benefit from price fluctuations in the value of assets, combined with excessive disproportionality of volumes and velocity of circulation of financial and real capital (Korneev, 2008). The effect of crowding out capital from the real sector to the area of speculative operations can be logically explained over high risks in coordination with the local market. In such a situation, investors will make decisions on investing only on condition of obtaining super-profits. So, we have a circle: high risks and instability stimulate the crowding out of capital into speculative operations, and, in turn, the growth of the speculative sector puts additional pressure on the economy, which leads to deepening crisis processes.

To the functions of credit ratings on the financial market belong:

- overcoming the information asymmetry of the financial market to make investment decisions and ensuring the investor's right to receive reasonable independent information about the creditworthiness of the borrower;

- resolution of principal-agent problems and credit risks monitoring in the term of managing investment portfolios and risk level regulation of capital investment and bank reserves regulation to cover loan losses;

- access to the stock, credit and deposit markets by setting the cut-off level in the form of a minimum rating, capital requirements for credit institutions;

- ensuring information security in order to achieve transparency and validity of decision-making mechanisms at all levels of the banking system, including the development of internal banking risk control and management systems;

- conditions optimization for attracting global capital to national financial markets.

The principles of rating agencies activity are:

- independence of ratings;

- publicity (availability) of analytical evaluation criteria;

- collegial decision-making procedures;

- interactivity;

- confidentiality;

- use of rating scales;

- continuous monitoring of issuer default probability;

- development of methodology.

Undoubtedly, the expected rate of return on capital invested in a risky environment should compensate risks. At the same time, in the case of a pre-default sovereign rating, quantitative risk assessments require a risk premium, the size of which will be much larger than the real sector of the economy can provide. So, a dilemma arises for investors: withdraw capital from a sector that does not provide a rate of return corresponding to a risk premium, or suffer economic losses in the form of the difference between the expected risk premium and actual financial results. We study the causal relationship of the risks of sovereign ratings, interest rates and capital migration from the real sector to the speculative. According to the traditional approach, the expected rate of return on capital invested in an enterprise depends on the risk-free (base) interest rate, the market average risk premium and the systematic risk of investing in a particular asset (beta factor). Since enterprises use both their own and borrowed capital to finance their activities, the weighted average rate of return on capital (WACC) is calculated to determine the total price of capital. The indicated interest rates serve as the basis for calculating the dis- 
count rate, which is an important calculation parameter for evaluating the effectiveness of investments, determining the fair value of assets and evaluating the value of a business. The country's sovereign ratings directly affect both the local risk-free interest rate and the average rate of return on the local market. Moreover, in different countries, the financial crisis may vary in their effect on interest rates. According to the results of KPMG research (KPMG - an international consulting company) in developed countries there is a tendency to increase market risk premium during the financial crisis (MRP). At the same time, the risk-free (basic) rate of return is somewhat reduced (KPMG, 2013). And states with low ratings are characterized by a significant increase in the latter. Risk-free financial instruments are characterized by the absence of default risks, currency risks and any other threats of losses by the investor. Since such instruments do not exist in nature, in practice they use returns on "quasi-risk-free" investments, which mainly include investments in government debt obligations. It should be understood that a risk-free rate of return does not mean a simple fixation of the current rate of return on government bonds. For this, a complex set of calculations is used, which provides for smoothing rates and analyzing the curve of the structure of interest rates for a certain period. One of the ways to determine the risk-free rate of return in countries with developed stock markets is using the Svenson method, which takes into account the complex relationships between the spot rate and the period of circulation of financial instruments (Svensson, 1995). This method is widely used by central banks of many countries to establish the base interest rate, however, due to the lack of reliable information to determine the local risk-free rate for Ukraine, this method is unacceptable today.

\section{Methods}

The influence of a country's sovereign ratings on a risk-free interest rate is carried out through the socalled country risk premium (CRP). Thus, the yield on government obligations within emerging markets is consisted of two components: the global risk-free rate and the country's risk premium. In the case of predefault ratings, the risk-free financial instruments issued by it are practically absent, since the country's risk premium is extremely high. So, the base interest rate can grow to a level that exceeds the yield on some corporate securities. This thesis can be confirmed by the dynamics of the discount rate of the National Bank of Ukraine, which during 2014 - 2015 was revised five times and grew more than 4.6 times. As in April 2015, the discount rate, which is the base interest rate for other NBU interest rates and refered to the currency price, and in some cases for a risk-free rate, has been increased to $30 \%$ (NBU, 2016). For comparison: in the euro area, the base interest rate during the 2009-2011 debt crisis reached its historical minimum at that time $0.12 \%$. At the same time, from January 1, 2013 the ECB introduced the establishment of a negative accounting interest rate, which since 2015 has been $0.83 \%$. In the USA, the interest rate since the end of 2008 is also at a historic low $(0.25 \%)$ level (Trading economics, 2019). The catastrophic situation with sovereign ratings and interest rates in Ukraine is caused by the presence of a complete set of risks on emerging markets described by T. Copeland and J. Murrin. These are high inflation, macroeconomic instability, increased state control over capital, political risks, the threat of military conflicts and civil unrest, changes in government regulation, a low culture of contractual relations, poor investor protection, and corruption (Copeland, Koller, Murrin, 2007). It is clear that under such circumstances, the calculation of the objective local risk-free rate loses its sence. As A. Tereshchenko points out, one of the points to solve this problem is to use the so-called global risk-free rate in the calculation of capital costs (Tereshchenko, Babiak, 2013). According to various estimates, its value ranges from 3 to $4 \%$. The application of this rate avoids the drawback that is widespread in theory and practice - double risk accounting when assessing the cost of capital invested in the local market (the market risk premium includes the global risk premium for developed countries and the country's additional risk premium) (Tereshchenko, 2010). At the same time, the global risk-free rate solves the information lack problem and the problem of interest rates base calculating for emerging market countries that are in the acute phase of the financial crisis.

Another important parameter for determining capital costs, which substantially depends on the country's sovereign rating, is the market average rate of return. It is clear that high risks directly affect the risk premium expected by investors. The average risk premium consists of a risk premium on developed markets (global risk premium) and a risk premium for investments in a certain country. As already noted, the second component is most sensitive to the level of sovereign ratings.

At the beginning of 2015, Ukraine's ratings fell to historic low level, respectively, the risk premium reached a maximum of $15 \%$. Taking into account the risk premium for countries with a developed stock market and minimal default risk (AAA rating), the market premium for investment risk in Ukraine has become $20.75 \%$. It is worth noting that the given values of the risk premium are estimated in US dollars. If they 
are broadcast in hryvnia equivalent (adjusted for inflation in Ukraine and the USA), we will get even higher risk premium values.

In addition, rational investing calculation takes into account the risk-free interest rate and the risks of investing in a particular asset (enterprise). For example, if the global risk-free rate is $3.5 \%$, and the systematic risk of investments (beta factor) into the enterprise (or an asset) is 1.5, then, if you use the CAPM model, the rate of return, which will compensate overall risks of the investor, will be $34,6 \%$ in US dollars. It is clear that the yield in hryvnia equivalent depends on the inflation rate in Ukraine, therefore, significantly exceeds its normalized rate. So, if in March 2015, compared to the same period of 2014, inflation in Ukraine amounted to $45.8 \%$, and in the United States - about $1.5 \%$, then as a result of the transformation of interest rates taking into account the level of inflation, we obtain the required rate of return at the level of $64 \%$ in hryvnias.

With high risks and, accordingly, a high discount rate, most investment projects in the real sector of the economy become unprofitable. Another negative consequence of high risks and low sovereign ratings is a decrease in the value of assets located in the country. In addition, the value of corporate enterprises as a business asset is significantly reduced. So, low sovereign ratings indicate the inexpediency of investing in industrial investments, fixed assets and enterprises on the local market.

Large financing risks can be justified only if it is possible to obtain super-profits. In the case of Ukraine (subject to systematic risks at the level of 1.5), the required return should exceed $34.6 \%$ in US dollars or $64 \%$ in hryvnias. For comparison: in developed countries it averages $8-12 \%$. Taking into account the level of risks, investments into the manufacturing sector are not able to ensure the economic return on investment. Therefore, capital investments are frozen, and investments are made only in the most speculative operations with signs of a shadow economy.

\section{Results}

In the case of limited opportunities, government policy should be aimed at localizing the reasons for the declining sovereign ratings, so that it will be possible to reduce the largest component of high interest rates a premium for country risk. We emphasize that a sovereign rating is derived from the level of risks, budget revenues and expenses, monetary policy, the state debt burden, the geopolitical situation, other factors of the state financial stability and the ability of the government and business entities to fulfill their obligations. In other words, it is not the credit rating that affects macroeconomic indicators and the level of risks, but vice versa. While working on raising the country's sovereign ratings, the main efforts should be directed on such risk generators as corruption, macroeconomic instability, low level of investors rights protection, frequent changes in the government regulation. The introduction of anti-crisis management elements is an adequate response of the corporate sector to modern challenges, in particular, risk management systems and anti-crisis financial controlling tools (Tereshchenko, 2004). We are talking about the need to introduce effective risk neutralization systems at enterprises, including those that have macroeconomic roots, which will reduce the risks of investing in the corporate sector compared to government financial instruments.

Another way to mitigate the factors of rapid growth in interest rates is to reduce the information asymmetry at both the macro and microeconomic levels. This refers primarily to the reduction of information risks of investors. This is a complex issue, that include ensuring transparency in the economic government activities, predictability of changes in regulatory legal acts, regulating business activities, implementing corporate governance principles (the key of which is openness of management to investors) at the level of business entities.

From a theoretical point of view, the reduction of the risks of investing capital in enterprises, and, consequently, the provision of investments in the real sector of the Ukrainian economy will be achieved if corporate finance carries out pricing and information functions. As A. Krysovaty, V. Fedosov, and N. Ryazanova prove, these functions are closely related: there are many examples when a company ended in capital losses, bankruptcy, and losses, the main reason for which was the distortion of primary data on corporate finances. The availability of proper financial and economic information and its effective exchange is a condition for the sustainable development of the corporation. Only if the uncertainty of economic relations is reduced, the latter can minimize or even completely eliminate the risks in its activities (Krysovaty, Fedosov, Ryazanov, 2013). Given the above, we believe that in the conditions of low sovereign ratings of Ukraine, the implementation of the latest technologies, financial decision-making and risk management can contribute to the solution of the task of raising capital by domestic enterprises. These technologies should be aimed at reducing the information asymmetry between investors and enterprises, as well as at ensuring the pricing interests of investors. One of the innovative tools to ensure the implementation of the pricing function of corporate finance is a value-oriented management system (VBM). The application of this approach to the imple- 
mentation of the financial policies of enterprises can somewhat mitigate the effects of information asymmetries between participants of financial relations and neutralize the conflict associated with it (Uhodnikov, 2014). The introduction of this system provides a fundamentally new philosophy of enterprise management, which includes establishing mutually beneficial relations with all interest groups, social responsibility to society and staff, value-oriented responsibility to investors, and the development of a culture of contractual relations. In combination with other measures, this will help to reduce the risks of investing into corporate sector and capital costs. On the one hand, the use of innovative methods of financial communication will contribute to the reduction of informational risks of creditors, and on the other hand, the assessment of creditworthiness and investment attractiveness of enterprises. The definition of credit risks should be based on empirical data on borrowers default statistics and on internal rating principles (Damodaran, 2010). The transition to a rating system for assessing credit risks will make it possible to harmonize technologies aimed at information asymmetry reducing and, therefore, reduce risks and interest rates. Another area of implementation of the corporate finance information function is the introduction of financial communication tools for enterprises to find potential investors. We are talking about a system for positioning an enterprise on the capital market as an attractive object for investment.

\section{Conclusion}

During the financial and economic crisis, the main parameters used in capital cost calculating are distorted anomalously. Low sovereign ratings and, accordingly, a high risk of default significantly affect the size and procedure for establishing a risk premium for investments in a certain state. Risk premium largely determines the level of local interest rates and, consequently, the cost of capital for the corporate sector. The risk premium directly affects the size of the risk-free (base) interest rate, as well as the average profitability in a particular local market. Thus, by changing the parameters that form the state's rating, it is possible to achieve a reduction in the risk premium for a particular country and at the same time interest rates in it. Given the interdependence of macro- and microeconomics, influence on the parameters that determine the ratings should be applied by both government bodies and corporate enterprises. In the context of capital costs, the difference between financial crises in countries with developed stock markets and in countries with developing markets lies in the nature of changes in interest rates, in particular, the base interest rate: in the first - it decreases, and in others - it increases on the contrary. High risks and the rate of return on invested capital determine the displacement of financial resources from the real sector of the economy into speculative operations. The growth in volumes of the latter turns into a factor of the financial crisis.

Sovereign ratings of a country are formed on the base of factors not controlled by the sovereign government (significant level of debt burden, external military dangers, closure of markets by individual states, a number of macroeconomic indicators), as well as controlled ones (level of corruption, protection of investor rights, inflation, most macroeconomic indicators, the quality of state regulation of economic processes). These factors should be focused on reforms that will ultimately contribute to improving the country's sovereign ratings. The usage of modern tools for doing business and making financial decisions is a definite safeguard for capital flow from the real sector to the speculative sector due to rising risks and the cost of capital. Such systems and technologies as financial controlling, value-oriented management, financial communications, modern methods of assessing credit risks are made to reduce investors' risks and increase investment attractiveness. Their practical recommendations, combined with macroeconomic reforms in the country, will help to improve the ratings of our state as a whole and individual business entities, and create favorable conditions for capital inflows into the real sector of the economy.

\section{Reference}

Braley, R., Myers, S. (2004). Principles of corporate finance. Moskow: ZAO Olimp-Business, 1008 p.

Copeland, T., Koller, T., Murrin, J. (2007). Cost of companies: evaluation and management. Moskow: CJSC "Olympus - Business", $576 \mathrm{p}$.

Damodaran, A. (2010). Investment assessment: tools and methods ratings of any assets. Moskow: Alpina Publishers, $1338 \mathrm{p}$.

Fernandez, P. (2004). The Value of Tax Shields and is NOT Equal to the Present Value of Tax Shields. Journal of Financial Economics, 2004. Vol. 73. PP. 145 - 165.

Global ratings. (2020). Retrieved from https://www.standardandpoors.com/en_US/web/guest/ratings/ratings-actions

Korneev, V. (2008). Financial speculation and sustainability economic systems. Economics and forecasting, Issue 2, PP. 24- 48 .

KPMG's Valuation News-Sammelband 2011-2013 PP. 42-45. Retrieved from https:/www.kpmg.com/de/de/bibliothek/valuation-news/seiten/ sammelband-valuation-news.aspx. 
Krysovaty, A., Fedosov, V., Ryazanov, N. (2013). Corporate finance in context of modern innovation calls of the economy. Finance of Ukraine, Issue 9, 2013, PP. 7- 27.

Lowenstein, R. (2008). Triple-AFailure: The Ratings Game. New York Times. Retrieved from http://www.nytimes.com/2008/04/27/maga-zine/27Credit-t.html

Mirkin, Y. (2014). Rating as an element sovereignty..Expert. Issue 6, 2014 , PP.

Moiseev, S. (2009). Regulation of rating agencies activities on national market. Questions of the economy, Issue 2, 2009, P. 39

Moody's downgrades Ukraine 's sovereign ratings to $\mathrm{Ca}$ outlook remains negative. Retrieved from https://www.moodys.com/.

Raksina, A. (2015). Rating import substitution. News. Retrieved from http:/www.newizv.ru/economics/2015-0910/227019-rejtingovoe-importozameshenie.html

Standard and Poor's. . Retrieved from https://www.standardandpoors.com/en_US/web/guest/ratings/ratings-actions

Svensson, L. (1995). Estimating Forward Interest Rates with the Extended Nelson. Soveriges Riskbank, Vol. 17, 1995, PP. 20-26.

Tereshchenko, A. (2004). Anticrisis financial management - is a requirement of "new economy". Market valuable papers of Ukraine, Issue 9, 2004, PP. 25 - 33.

Tereshchenko, A. (2010). The discount rate in financial investment decision making. Finance Of Ukraine, Issue. 9, 2010, PP. 77- 91.

Tereshchenko, V., Babiak, N. (2013). Financial controlling. Kyiv National economic university named after Vadym Hetman, 2013, 407 p.

The discount rate of the National Bank of Ukraine (2016). Retrieved from http://www.bank.gov.ua/control/uk/publish/article?art_id=53647

Trading Economics. (2019). Retrieved from http://ru.tradingeconomics.com/euro-area/interest-rate.

Uhodnikov, K. (2014). Quality mark. Retrieved from https : // lenta. com / articles / 2014/04/23 / reiting /

\section{Е.А. Борзенко}

\section{Украинаның егеменді рейтингтері: факторлар мен қауіптер}

\section{Aңдатna}

Maқ̧саты: Мақаланың мақсаты қаржы нарығындағы егеменді несиелік рейтингтердің мазмұнын, функциялары мен рөлін ашатын теориялық ережелерді дамыту, дағдарыс кезеңінде егеменді рейтингтерді анықтаудың әдістемелік тәсілдерін өзгертуді негіздеу және Украинадағы рейтингтік агенттіктердің қызметін реттеу бөлігінде ұсынымдар әзірлеу болып табылады.

Әдісі: Мақаланың әдіснамалық негізі жалпы экономикалық теорияның ережелері, жүйелік тәсіл, тренд негізінде болжау әдісі, аналитикалық теңестіру әдістері, статистикалық әдіс болып табылады.

Kорытынды: Зерттеу нәтижесінде елге алыпсатарлық деңгейдегі рейтингтер берілген жағдайда капиталдың көп бөлігі қысқа мерзімді сипаттағы алыпсатарлық операцияларға ауысатыны анықталған. Тәуекелділіктің жоғары болуы, микро және макроэкономикалық белгісіздік, мемлекеттің экономикалық ортаға және елдегі процестерге және нарыққа қатысушылардың ықпалының шектеулі мүмкіндіктері алыпсатарлық капиталдың қозғалысы үшін мінсіз орта жасайды.

Тұжырымдама: Капиталдың нақты сектордан алыпсатарлық секторға ағуының белгілі бір сақтандырғышы - тәуекелдердің өсуі мен капитал құнының салдарынан бизнесті жүргізудің және қаржы-экономикалық шешімдерді қабылдаудың қазіргі заманғы құралдарын пайдалану болып табылады. Инвесторлардың тәуекелдерін азайтуға және инвестициялық тартымдылықты арттыруға қаржылық бақылау, құндылықтыбағдарланған басқару, қаржылық коммуникациялар, кредиттік тәуекелдерді бағалаудың қазіргі заманғы әдістері және т.б. сияқты инновациялық жүйелер мен технологиялар бағытталған. Олардың елдегі макроэкономикалық реформалармен кешенді практикалық ұсыныстары біздің мемлекетіміздің және шаруашылық жүргізудің жекелеген субъектілерінің рейтингтерін жақсартуға көмектеседі, экономиканың нақты секторына капиталдың келуі үшін қолайлы жағдай жасайды.

Kiлm сөздер: егеменді рейтингтер, экономиканың корпоративтік секторы, кредиттік-инвестициялық рейтингтер, алыпсатарлық рейтингтер, капитал.

\section{Е.А. Борзенко}

\section{Суверенные рейтинги Украины: факторы и риски}

\section{Аннотация}

Цель: Целью статьи является развитие теоретических положений, раскрывающих содержание, функции и роль суверенных кредитных рейтингов на финансовом рынке, обоснование трансформации методических под- 
ходов к определению суверенных рейтингов в период кризиса и выработка рекомендаций в части регулирования деятельности рейтинговых агентств в Украине.

Memoдbl: Методологической основой статьи послужили положения общей экономической теории, системный подход, метод прогнозирования на основе тренда, методы аналитического выравнивания, статистический метод.

Результаты: В результате исследования установлено, что в случае присвоения стране рейтингов спекулятивного уровня большая часть капитала перетекает в спекулятивные операции краткосрочного характера. Высокая рискованность, микро- и макроэкономическая неопределенность, ограниченные возможности влияния государства на экономическую среду и на процессы в стране и участников рынка создают идеальную среду для движения спекулятивного капитала.

Bblвoдbl: Определенным предохранителем перетекания капитала из реального сектора в спекулятивный сектор, вследствие роста рисков и стоимости капитала, являются использование современных инструментов ведения бизнеса и принятие финансово-экономических решений. Уменьшить риски инвесторов и повысить инвестиционную привлекательность призваны такие инновационные системы и технологии, как финансовый контроллинг, ценностно-ориентированное управление, финансовые коммуникации, современные методы оценки кредитных рисков и т.п. Их практические рекомендации в комплексе с макроэкономическими реформами в стране помогу улучшить рейтинги нашего государства в целом и отдельных субъектов хозяйствования, создадут благоприятные условия для притока капитала в реальный сектор экономики.

Ключевые слова: суверенные рейтинги, корпоративный сектор экономики, кредитно-инвестиционные рейтинги, спекулятивные рейтинги, капитал.

\section{References}

Fernandez P. The Value of Tax Shields us NOT Equal to the Present Value of Tax Shields / P. Fernandez // Journal of Financial Economics. 2004. — № 73. - P. 145-165.

KPMG's Valuation News - Sammelband. - (https://www.kpmg.com/de/de/bibliothek/valuation-news/seiten/ sammelband-valuation-news.aspx).

Lowenstein R. Triple-A Failure: The Ratings Game / R. Lowenstein. New York Times. (http://www.nytimes.com/2008/04/27/maga-zine/27Credit-t.html).

Moody's downgrades Ukraine's sovereign ratings to Ca; outlook remains negative. — ( https://www.moodys.com/).

Standard and Poor's. — (URL: https://www.standardandpoors.com/en_US/web/guest/ratings/ratings-actions ).

Svensson L. Estimating Forward Interest Rates with the Extended Nelson -Siegel Method / L. Svensson // Soveriges Riskbank. - 1995. - № 17. - P. 13-26.

Брейли Р. Принципы корпоративных финансов / Р. Брейли, С. Майерс; пер. с англ. Барышникова. - М.: ЗАО «Олимп-Бизнес», 2004. - 1008 с.

Дамодаран А. Инвестиционная оценка: инструменты и методы оценки любых активов / А. Дамодаран; пер. с англ. - 6-е изд. - М.: Альпина Паблишерз, 2010. - 1338 с.

Корнеев В.В. Финансовые спекуляции и устойчивость экономических систем / В.В. Корнеев // Экономика и прогнозирование. - 2008. - № 2. - С. 24-48.

Коупленд Т. Стоимость компаний: оценка и управление / Т. Коупленд, Т. Коллер, Дж. Муррин; пер. с англ. 3-е изд. - М.: ЗАО «Олимп-Бизнес», 2007. — 576 с.

Крысоватый А.И. Корпоративные финансы в контексте вызовов современной инновационной экономики / А.И. Крысоватый, В.М. Федосов, Н.С. Рязанова // Финансы Украины. — 2013. — № 9. — С. 7-27.

Миркин Я.М. Рейтинг как элемент суверенитета / Я.М. Миркин // Эксперт. — 2014. — № 6. — С. 56-71.

Моисеев С.Р. Регулирование деятельности рейтинговых агентств на национальном рынке / С.Р. Моисеев // Вопросы экономики. - 2009. - № 2. - С. 39.

Раксина А. Рейтинговое импортозамещение / А. Раксина // Новые известия. — 2015. - (URL: http://www.newizv.ru/economics/2015-09-10/227019-rejtingovoe-importozameshenie.html).

Trading Economics. — (URL : http://ru.tradingeconomics.com/euro-area/interest-rate).

Терещенко А. Антикризисный финансовый менеджмент - требование «новой экономики» / А. Терещенко // Рынок ценных бумаг Украины. - 2004. - № 9. - С. 25-33.

Терещенко А.А. Ставка дисконтирования в принятии финансово-инвестиционных решений / А.А. Терещенко // Финансы Украины. - 2010. — № 9. - С. 77-91.

Терещенко В.А. Финансовый контроллинг / В.А. Терещенко, Н.Д. Бабяк // ДВНЗ «Киев. нац. экон. ун-т им. В. Гетьмана». - 2013. - 407 с.

Угодников К. Знак качества / К. Угодников. — (URL: https://lenta.ru/articles/2014/04/23/reiting/).

Учетная ставка Национального банка Украины / Нац. банк Украины. — (URL: http://www.bank.gov.ua/control/uk /publish/article? art_id=53647) 